\title{
High-elevational occurrence of two tick species, Ixodes ricinus and I. trianguliceps, at their northern distribution range
}

\author{
Nicolas De Pelsmaeker ${ }^{1 *}$ (D) Lars Korslund ${ }^{2}$ and Øyvind Steifetten ${ }^{1}$
}

\begin{abstract}
Background: During the last decades a northward and upward range shift has been observed among many organisms across different taxa. In the northern hemisphere, ticks have been observed to have increased their latitudinal and altitudinal range limit. However, the elevational expansion at its northern distribution range remains largely unstudied. In this study we investigated the altitudinal distribution of the exophilic Ixodes ricinus and endophilic I. trianguliceps on two mountain slopes in Norway by assessing larval infestation rates on bank voles (Myodes glareolus).

Methods: During 2017 and 2018, 1325 bank voles were captured during the spring, summer and autumn at ten trapping stations ranging from $100 \mathrm{~m}$ to $1000 \mathrm{~m}$.a.s.l. in two study areas in southern Norway. We used generalized logistic regression models to estimate the prevalence of infestation of both tick species along gradients of altitude, considering study area, collection year and season, temperature, humidity and altitude interactions as extrinsic variables, and host body mass and sex as intrinsic predictor variables.

Results: We found that both I. ricinus and I. trianguliceps infested bank voles at altitudes up to 1000 m.a.s.l., which is a substantial increase in altitude compared to previous findings for I. ricinus in this region. The infestation rates declined more rapidly with increasing altitude for I. ricinus compared to I. trianguliceps, indicating that the endophilic ecology of I. trianguliceps may provide shelter from limiting factors tied to altitude. Seasonal effects limited the occurrence of $I$. ricinus during autumn, but I. trianguliceps was found to infest rodents at all altitudes during all seasons of both years.

Conclusions: This study provides new insights into the altitudinal distribution of two tick species at their northern distribution range, one with the potential to transmit zoonotic pathogens to both humans and livestock. With warming temperatures predicted to increase, and especially so in the northern regions, the risk of tick-borne infections is likely to become a concern at increasingly higher altitudes in the future.
\end{abstract}

Keywords: Ticks, Altitude, Ixodes ricinus, Ixodes trianguliceps, Bank vole, Myodes glareolus, Distribution, Range shift

\section{Background}

During the last decades increasing temperatures have been shown to have an impact on the distribution of species across a wide range of taxonomic groups $[1,2]$.

*Correspondence: nicolas.de.pelsmaeker@usn.no

${ }^{1}$ Department of Nature, Health and the Environment, University of South-Eastern Norway, Bø, Norway

Full list of author information is available at the end of the article
Depending on the species' adaptability to a warmer climate and the ability to disperse, species may either (i) increase their distribution range due to conditions becoming more favourable in areas that were previously inhospitable [3, 4]; (ii) contract in range as their habitat becomes increasingly unsuitable $[5,6]$; or (iii) move away from areas that have become unsuitable towards habitats that have become more favourable $[7,8]$. To date most species appear to expand their natural distribution range, 
and for the majority of species both a northward $[9,10]$ and an upward [11-13] range expansion seems to be the most common movement pattern.

Along with other organisms, certain ectoparasites, such as ticks, have undergone similar range expansions [14-16]. Ticks are generally limited in their distribution by environmental factors, such as temperature and humidity $[17,18]$, but as hematophagous parasites they also depend on the presence of adequate hosts [19]. With a changing climate, ticks have been observed to have increased their distribution range northwards in the northern hemisphere [20-22], and several studies have also demonstrated the occurrence of ticks at increasingly higher altitudes in central Europe [14, 23, 24]. For example, in Switzerland, Ixodes ricinus has been recorded at altitudes up to 1070 m.a.s.l. [25, 26], and in the Czech Republic this species has shifted its altitudinal range limit up to 700 m.a.s.l. since the 1990s [27], and in one instance up to 1100 m.a.s.l. [28]. According to Danielova et al. [29], it may survive up to 1200 m.a.s.l. or higher if the habitat is favourable. Another tick species, I. trianguliceps, has been recorded at altitudes as high as 2300 m.a.s.l. in Switzerland [30], but because it does not quest in open vegetation like I. ricinus, it is likely to be less exposed to limiting environmental conditions, especially temperature, and hence able to survive in more extreme environments [19]. With any upward shift in range limit, the risk of exposure to tick-borne infections is likely to increase for both humans and livestock $[24,28]$, and is predicted to further increase in the future [31-33].

Most studies investigating the altitudinal dynamics of $I$. ricinus have occurred at its geographical center in Europe $[14,26,29,34]$, and very little is known about its altitudinal distribution at the northern range. Because the effects of climate change are expected to be stronger at higher latitudes [35], the increase in altitude expansion is likely to be more pronounced in Scandinavia. In Norway, $I$. ricinus has undergone a northward range shift similar to that observed in other Scandinavian countries [36-38], with the shift found as far north as $69^{\circ} \mathrm{N}$ [15] and considered to be permanently established at $66^{\circ} \mathrm{N}$ [39]. It has also expanded upwards in altitude and based on direct and indirect multi-source analysis reported by citizens, hunters, health professionals and veterinarians, has been observed up to 583 m.a.s.l. [15]. Even so, data are scarce, and the occurrence of ticks in relation to altitude and its range boundary remain largely unknown.

To the best of our knowledge, no recent field studies have investigated the altitudinal distribution of ticks at their northern distribution range in Europe. The aims of this study are to determine the altitudinal distribution patterns of the generalist tick I. ricinus and the specialist tick I. trianguliceps in Norway, by studying the infestation rates of both species on a commonly found rodent, the bank vole (Myodes glareolus). Because of the nest-dwelling behaviour of $I$. trianguliceps, we expect it to be less limited by altitude than I. ricinus.

\section{Methods \\ Study areas}

This study was carried out along two mountain slopes in Norway during 2017 and 2018 (Fig. 1). The first study area was a south-facing mountain slope on the Lifjell massif $\left(59^{\circ} 26.495^{\prime} \mathrm{N}, 9^{\circ} 0.603^{\prime} \mathrm{E}\right)$, north of Bø i Telemark. It is characterized by a continental climate, located within the boreonemoral to southern boreal zone. Below the tree line, which is situated between 800 and 900 m.a.s.l., the vegetation is a blend of deciduous and coniferous forests with birch (Betula pubescens) and spruce (Picea abies) as the dominant tree species, and blueberries (Vaccinium myrtillus) as the dominant species at ground layer. Below the tree line the vegetation is mostly homogeneous. Above the tree line the vegetation is primarily dominated by common heather (Calluna vulgaris) and blueberries. Boulder fields occur frequently throughout the gradient, and the highest peak found on the plateau is 1288 m.a.s.l. Most of the data collection points were located on topographically open hillside. Temperature and precipitation normals for the study areas can be found in Appendix 1. The second study area was located in the Erdal valley $\left(61^{\circ} 05.817^{\prime} \mathrm{N}, 7^{\circ} 24.688^{\prime} \mathrm{E}\right)$ near Lærdalsøyri (hereafter referred to as Lærdal). It is a northfacing mountain slope close to the innermost part of the Sognefjorden fjord, approximately $150 \mathrm{~km}$ east of the western coastline. Due to its proximity to the ford, the climate is more maritime than that at Lifjell, characterized by cooler summers and milder winters (Appendix 1). Sampling points were mostly located within the valley formed by the Erdal river. The tree line here is situated between 900 and 1000 ma.s.l., and below the tree line the vegetation consists primarily of homogeneous deciduous forests with birch and alder (Alnus glutinosa) as the dominant tree species. At ground layer the vegetation is dominated by blueberries, and different species of ferns and tall perennial herbs. Above the tree line common heather, dwarf birch (Betula nana), common juniper (Juniperus communis) and crowberry (Empetrum nigrum) are the dominant species. Surrounding the study area are several mountain peaks exceeding 1500 m.a.s.l.

\section{Study species}

Ixodes ricinus is the most common and the most studied tick species in Europe [18]. It ranges latitudinally from North Africa to Scandinavia, and longitudinally from Ireland to Russia [40]. It is a three-host tick that feeds on a wide range of mammals, birds and reptiles 
[41]. Immature life stages (larvae and nymphs) parasitize small mammals in larger proportions [42], whereas adults tend to feed on larger mammals [41]. It is common to deciduous and, to some extent, coniferous forests and is dependent on sufficient temperature and humidity to be able to quest (actively seeking a host). It is sensitive to desiccation and temperature extremes [43].

Ixodes trianguliceps occurs throughout Europe, ranging latitudinally from Italy up to well above the Arctic Circle [44]. Contrary to I. ricinus, I. trianguliceps specializes primarily on rodents and other small mammals during all life stages $[45,46]$. It is endophilic (nest-dwelling), spending its off-host time within the burrows of its host to moult and quest [47]. It occurs in widely different habitats, ranging from meadows, peat bogs to dark-coniferous forests, mixed and deciduous forests, as well as high-altitude treeless zones [42, 45]. It is generally considered to be one of the most cold-resistant ticks of the genus Ixodes in the Palearctic region [45]. Since it rarely infests humans or livestock due to its host-seeking behaviour [48], cases of tick-borne infection are considered exceptional [15], but it does contribute to maintaining the infection cycle of several pathogens between $I$. ricinus and their hosts, such as Borrelia burgdorferi [49] and Anaplasma phagocytophilum [50].

The bank vole is a commonly found rodent throughout Europe and occurs virtually everywhere in Fennoscandia [51]. It is the most common rodent species in both study areas. Other small mammal species present in the study areas are the field vole (Microtus agrestis), tundra

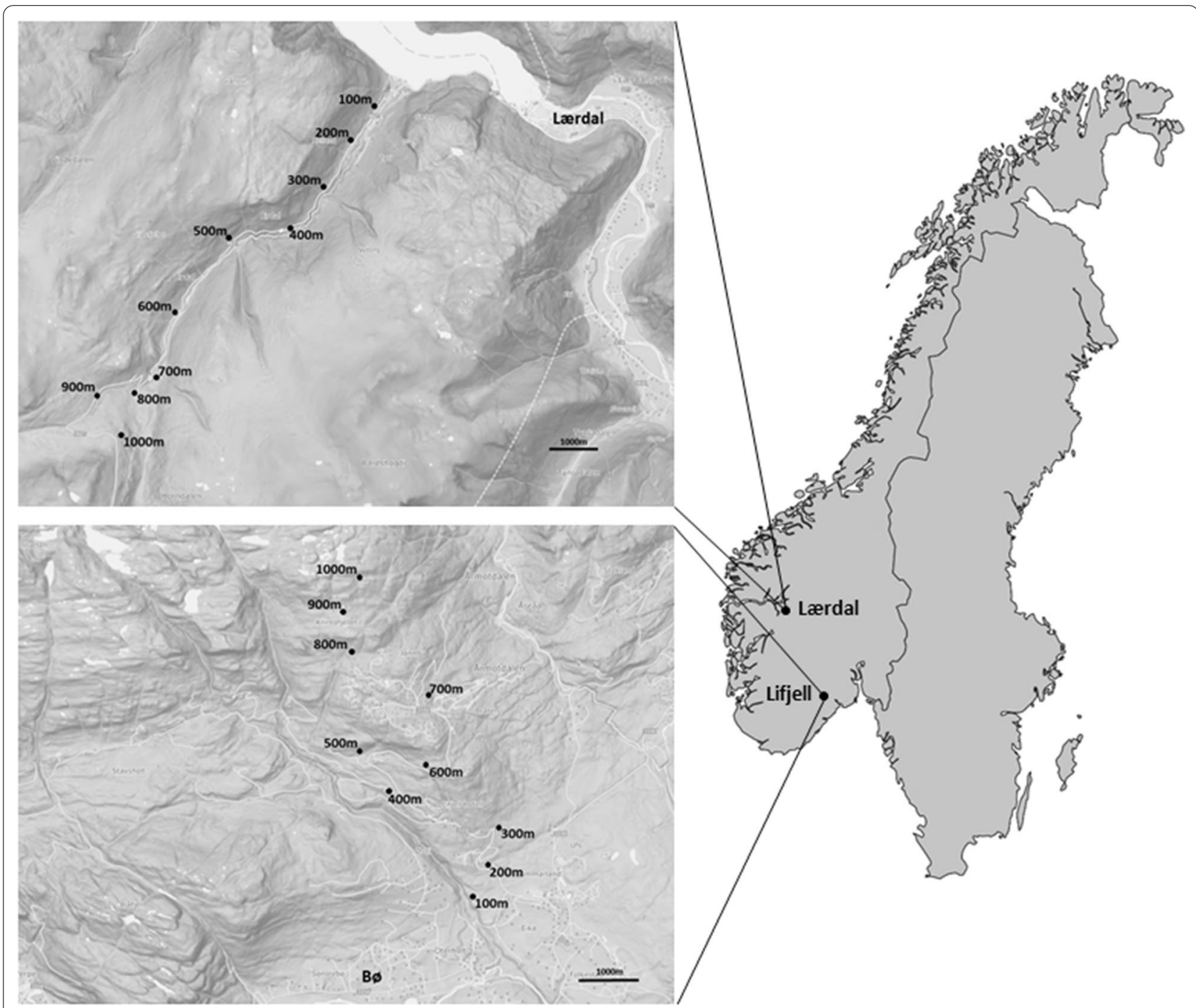

Fig. 1 Location of the two study areas in Norway. Inset maps show the exact location of each trapping station along the altitudinal gradient in Lifjell and Lærdal. Each trapping station was placed at every 100-m altitude interval, ranging from 100 to 1000 m.a.s.l. 
vole (M. oeconomus), grey red-backed vole (Myodes rufocanus), wood mouse (Apodemus sylvaticus), yellownecked mouse (A. flavicollis) and house mouse (Mus musculus). The common shrew (Sorex araneus), pigmy shrew (S. minutus) and water shrew (Neomys fodiens) are also found in these areas. The bank vole is a reservoir host for several tick-borne pathogens, such as B. burgdorferi [52], Babesia microti [53], Candidatus Neoehrlichia mikurensis [54] and A. phagocytophylum [55]. It is possibly the most important host for all life stages of I. trianguliceps [42] and is heavily infested by the immature stages of I. ricinus $[56,57]$. Because it was common at both study areas and at all altitudes, we chose to base our analysis on this species.

\section{Host trapping}

Ticks are commonly collected by two methods: clothdragging for questing (unfed) ticks and host examination for feeding ticks. The cloth-dragging method is only applicable for the collection of exophilic species, and only when the vegetation is dry. During most days of data collection the vegetation was either partly wet or weather conditions did not allow for cloth-dragging. Additionally, as we aimed to include the infestations of I. trianguliceps in this study, we focused solely on the capturing of hosts. However, examining tick burdens accurately from live small mammals can be difficult [58]; therefore, we opted for a combination of lethal traps and euthanized live captures. In both study areas, ten trapping stations were set up along a vertical gradient ranging from 100 to 1000 m.a.s.l. at every $100-\mathrm{m}$ altitude interval. Bank voles have relatively small home ranges [59], and altitude trapping stations were located several hundred meters from each other; hence we can be reasonably confident that ticks collected from a host at a certain altitude were also acquired in the immediate vicinity. At each trapping station, two plots of 20 traps each were deployed, one plot with live traps (Ugglan Special Nr. 2; Grahnab AB, Gnosjö, Sweden; http://www.grahnab.se), and the other plot with lethal traps (Rapp2 Mousetrap; Nordenfjeldske Børstefabrikk AS, Surnadal, Norway; http://www. rappfellene.no). The traps in both plots were arranged in a $4 \times 5$ grid, with a spacing of $10 \mathrm{~m}$ between each trap. Live traps were baited with a slice of apple for hydration and whole oats for caloric value, and a lining of sawdust was provided on the trap floor as insulation. Lethal traps were baited with peanut butter for practical reasons as it is easily applied to the inside of the trap body. Trap type does not influence tick burden size on the captured animals [60]. At each altitude, the live and lethal plots were placed at approximately $100 \mathrm{~m}$ distance from each other, but in locations with similar vegetation structure and habitat characteristics. As humidity and temperature have a direct influence on tick activity, they are important drivers of phenological patterns and host-seeking behaviour [61]. For this reason, a datalogger (TinyTag Plus 2TGP 4017, housed in a DataMate ACS-5050 instrument cover; Hastings Data Loggers, Port Macquarie, Australia) was placed in between the two plots at each trapping station, approximately $50 \mathrm{~cm}$ above ground level, for measuring air temperature and relative air humidity at 1 -h intervals for the duration of the trapping period. The height of $50 \mathrm{~cm}$ was chosen to capture the general variation in environmental conditions at each altitude. Trapping took place during the spring (20-30 May), summer (20-30 July) and autumn (20-30 September) seasons of 2017 and 2018. As an exception, during the spring season of 2017, capturing took place from 1 to 7 June, and only up to 700 m.a.s.l. in both areas, as there was too much snow to allow for the operation of traps earlier and above this altitude. During each trapping period, traps were checked every $24 \mathrm{~h}$, and the collection of trapped animals started at 08:30 h. When checking the trapping grids, triggered lethal traps were rebaited and reset. As examining live small mammals for ticks can be stressful and cause injury or death [62], all animals captured in live traps were euthanized by cervical dislocation of the head upon collection, and each individual was kept separately in a sealed and coded plastic bags. Activated live traps were emptied of the remaining contents, and new insulation and food were provided before resetting the traps. At the end of every collection day, all animals were placed in a freezer at $-20^{\circ} \mathrm{C}$.

\section{Laboratory processing}

At the end of every trapping season, captured bank voles were examined for ticks in the laboratory, as a full-body post-mortem examination provides the highest degree of sensitivity [63]. The day before the examination, the voles were removed from the freezer and left to thaw overnight at $10{ }^{\circ} \mathrm{C}$. The voles were examined one by one and taken out of the plastic bags individually. The empty bags were checked for ticks that might have dropped off. It was our observation that a number of ticks would drop off the host when the animals were placed in the freezer, possibly in an attempt to escape the extreme temperatures. Animals that were wet were dried with a hairdryer before examination. The hosts were checked for ticks starting with the head, ears and snout, followed by the neck and throat, back and abdomen, legs, feet and tail. Attached or detached ticks were removed from the host using tweezers. Collected ticks were removed and placed in a $1.5-\mathrm{ml}$ plastic Eppendorf tube containing a $70 \%$ ethanol solution (1 vial per host). Finally, a lice comb was brushed through the fur of the animal from tail to head (against the hair orientation), and the vole was shaken by the tail above 
a white plastic tray to collect any ticks that might have been missed during the examination. The hosts were then weighed to the nearest tenth of a gram, and the sex was determined. The minimum amount of time needed to process one animal was $20 \mathrm{~min}$. After the examination, the animals were bagged in new plastic bags and refrozen at $-20^{\circ} \mathrm{C}$.

Ticks were determined for life stage and species under a Zeiss Discovery V20 stereomicroscope (Carl Zeiss AG, Oberkochen, Germany), using an established publication key as reference [64]. Because more than 94 and $75 \%$ of all I. ricinus and I. trianguliceps collected, respectively, were larvae, only the larval stage was included in the analysis.

\section{Data analysis}

The statistical analyses were performed using the software package R version 3.5.3 [65]. The analysis of I. ricinus larvae and $I$. trianguliceps larvae was performed separately. As is usually the case with tick presence on small mammals, neither tick species was evenly distributed on the hosts [66], and 13.8 and $82.0 \%$ of the hosts had no $I$. ricinus and I. trianguliceps larvae present, respectively. We therefore chose to use the presence or absence of larvae as the response variable and applied generalized linear modelling with a binomial distribution, i.e. logistic regression. The probability of encountering a tick was defined as prevalence. As predictor variables we considered altitude (ranging from 100 to 1000 m.a.s.l., as a continuous variable), study area (Lifjell and Lærdal), collection year (2017 and 2018), season (spring, summer and autumn) and humidity (\%). Because altitude and temperature were negatively correlated (Pearson correlation test: $t=-8.1578, d f=1323, p<0.001, r=-0.219$ ), temperature per se was not used as a predictor variable in order to avoid introducing collinearity into the model. Two-way interactions between season and altitude, study area and altitude, year and altitude, study area and year, as well as year and season were included in the starting model. We also considered individual bank vole body mass (in grams) and sex (male or female) as intrinsic covariates. Starting with a full starting model containing all variables and the two-way interactions listed above, we used a backward step model selection process to progressively remove non-significant predictors, by comparing the residual deviance and degrees of freedom of nested models using a Chi-square test $\left(X^{2}\right)$, until an optimal model that contained only significant predictor variables $(\alpha=0.05)$ was found. To visually represent the infestation probabilities of both species across study areas, collection years and seasons, we created multiple regression line plots using the ggplot2 package in R [67].

\section{Ethics statement}

This study was carried out in strict accordance with regulations issued by the Norwegian Environment Agency, and a permit was provided prior to the start of the sampling (Miljødirektoratet, reference number: 2017/4651) for the duration of the trapping period. The trapping protocol for animal capture was approved by the Animal Ethics Committee of the Department of Nature, Health and Environment (University of South-Eastern Norway). All efforts were made to minimize animal suffering.

\section{Results}

During 2017 and 2018, a total of 43,920 trap nights was performed, capturing 1325 bank voles (976 and 349 captures in 2017 and 2018, respectively). Altogether 5372 tick larvae were collected from the trapped voles at all altitudes of the gradient. Larvae of I. ricinus were 7.4fold more numerous than those of $I$. trianguliceps (88.1 and $11.9 \%$ of ticks, respectively). Larval burdens ranged from one to 100 ticks for I. ricinus (mean $\pm 95 \%$ confidence interval $[\mathrm{CI}]: 3.6 \pm 0.5)$ and from one to 29 for $I$. trianguliceps (mean $\pm 95 \%$ CI: $0.5 \pm 0.1$ ), and more than half of the bank voles $(57.4 \%)$ were infested with at least one larva of either tick species. For I. ricinus and I. trianguliceps, respectively, 46.8 and $18.0 \%$ of voles carried at least one larva. Of all the voles, $7.3 \%$ were infested with at least one larva of both tick species. The total number of ticks collected from voles at every altitude is shown in Fig. 2. Mean burdens can be found in Appendix 2. An overview of all captured host species and infestation rates is listed in Appendix 3.

\section{Ixodes ricinus}

The best model shows that there was a clear negative overall effect of altitude on the prevalence of $I$. ricinus presence $(Z=-3.954, P<0.001)$, and a significant interaction between altitude and season $\left(\chi^{2}=12.3, d f=2\right.$, $P=0.002)$ illustrates that this effect was stronger in the autumn than in the spring and summer (Table 1; Fig. 3). In addition, a significant interaction between altitude and site $\left(\chi^{2}=11.1, d f=1, P<0.001\right)$ shows that the negative altitude effect was stronger in Lærdal than in Lifjell (Table 1 ), driven mainly by the fact that, while the prevalence is low at 1000 m.a.s.l. at both sites, the prevalence at the lower altitudes was higher in Lærdal (close to 1) than in Lifjell (around $\leq 0.75$ ) (Fig. 3). The model further shows that the overall prevalence of I. ricinus was highest among voles captured in the spring and lower, but not significantly lower, among voles captured in the summer $(Z=-1.14, P=0.25)$ and significantly lower among voles captured in the autumn $(Z=-2.65, P=0.08)$ (Table 1; Fig. 3). The prevalence of I. ricinus was overall lower in $2018(Z=-2.06, P=0.04)$, but the seasonal effect, with 


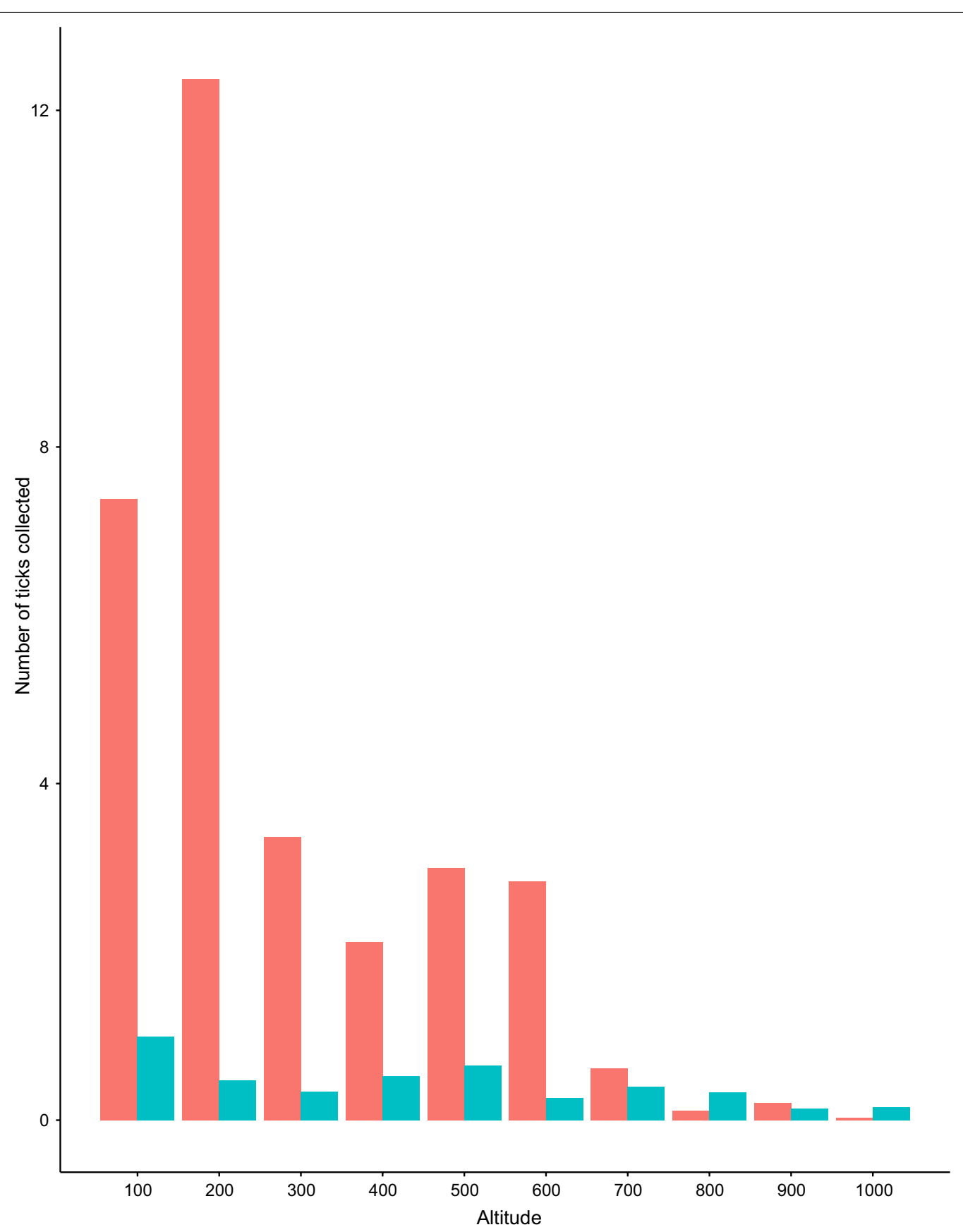

Fig. 2 Total number of tick larvae collected from bank voles (Myodes glareolus) per altitude (m a.s.l.), for both study areas, years and seasons combined. Red bars: Ixodes ricinus; blue bars: I. trianguliceps

lower prevalence in the autumn, was much stronger in 2017 than in 2018, as indicated by a significant interaction between year and season $\left(\chi^{2}=26.7, d f=2, P<\right.$ 0.001) (Table 1; Fig. 3). Finally, the significant interaction between site and season shows that the effect of season was stronger in Lærdal than in Lifjell $\left(\chi^{2}=12.3, d f=2\right.$, $P=0.002)$, with especially the autumn prevalence being lower in Lærdal $(Z=-2.73, P=0.006)$ (Table 1; Fig. 3).

While host weight did not affect the prevalence of $I$. ricinus $\left(x^{2}=0.106, d f=1, P=0.75\right)$, ticks were found 
(See figure on next page.)

Fig. 3 Prevalence of ticks on bank voles along an altitudinal gradient in Lifjell 2017 (a), Lærdal 2017 (b), Lifjell 2018 (c) and Lærdal 2018 (d). A prevalence of 1.0 represents a certainty of encountering at least one tick. Solid lines denote seasons: spring (green), summer (blue), autumn (red). Shaded areas around each coloured line represent the standard error $95 \%$ confidence intervals. For I. trianguliceps the spring and summer curves are closely overlapping

significantly more often found on male hosts than on female hosts, resulting in a significant sex effect in the best model $\left(\chi^{2}=15.0, d f=1, P<0.001\right)$.

\section{Ixodes trianguliceps}

The best model explaining the prevalence of I. trianguliceps on bank voles was ultimately found to be much simpler than that for I. ricinus (Table 1). Also for this species there was a clear negative overall effect of altitude on prevalence $\left(\chi^{2}=11.7, d f=1, P<0.001\right)$ (Table 1 ); however, the overall prevalence was much lower than that found for I. ricinus (Fig. 3). The overall prevalence of $I$. trianguliceps was significantly lower in Lærdal than in Lifjell $\left(\chi^{2}=34.7, d f=1, P<0.001\right)$ and significantly higher in 2018 than in $2017\left(\chi^{2}=27.0, d f=1, P<0.001\right)$ (Table 1; Fig. 3). The model further shows a clear effect of season $\left(x^{2}=35.7, d f=2, P<0.001\right)$, with the overall prevalence of $I$. trianguliceps being higher among voles captured in the autumn and with an equal prevalence in spring and summer (Table 1; Fig. 3).

Neither host weight $\left(\chi^{2}=2.66, d f=1, P=0.10\right)$ nor host $\operatorname{sex}\left(\chi^{2}=1.11, d f=1, P=0.29\right)$ affected the prevalence of I. trianguliceps presence on bank voles.

\section{Discussion}

The highest recorded observation for I. ricinus has up until now been 583 m.a.s.l. [15], but our study shows that both $I$. ricinus and I. trianguliceps were present at an altitude of at least 1000 m.a.s.l. in two locations located in the eastern and western part of southern Norway. We can therefore assume that in this region, both species are established at altitudes up to 1000 m.a.s.l.

\section{The effect of altitude on prevalence}

Although both tick species decreased in abundance with increasing altitude, both were found at all altitudes of the gradient. We expected altitude to have a stronger effect on I. ricinus than on I. trianguliceps, and our results support this expectation. While the prevalence of I. ricinus larvae was generally higher than that of I. trianguliceps at low altitudes, infestation of the former showed a stronger decline with increasing altitude during all three seasons than did infestation the latter, and this seems mostly a result of a much higher prevalence of this species at lower altitudes. The strongest decline in I. ricinus occurred during the autumn season, when the prevalence at the top of the gradient (above 900 m.a.s.l.) was zero, while still a substantial proportion of the hosts were infested at lower altitudes. Bown et al. [68] showed that excluding roe deer (Capreolus capreolus) as tick hosts reduces the larval burden of $I$. ricinus on small rodents, but not that of $I$. trianguliceps. The generally higher I. ricinus prevalence at lower altitudes in our study might therefore be caused by I. ricinus being able to make use of cervids as hosts, since we expect such hosts to be more common at the lower altitudes. At higher altitudes it is possible that both tick species are limited by the lower overall temperatures and/or the shorter snow-free season, but that I. trianguliceps is less affected due to its endophilic nature. It is reasonable to assume that $I$. ricinus cannot be active for as many days at $1000 \mathrm{~m}$ as at lower altitudes, which would reduce the probability of finding a host, ultimately leading to a lower population density. Ixodes trianguliceps, however, seeking a small mammal host within its burrows, is not as limited by low ambient temperatures [69] and should thus be more capable of completing its lifecycle at higher altitudes. This distinction might explain the different decline with altitude for these two tick species in our study.

Persistence of tick populations at high altitudes is not necessarily restricted by survival, molting success or oviposition $[17,30]$; rather, reduced hatching success is what prevents the establishment of populations [30]. The presence of feeding larvae on rodents at high altitudes in this study indicates that the two species are capable of completing their life-cycle. Because our study did not cover locations above 1000 m.a.s.l., the actual altitudinal range limit of $I$. ricinus and I. trianguliceps in these areas of Norway is still unknown. Nonetheless we have documented I. ricinus presence far above what has previously been reported [15].

\section{The effect of season on prevalence}

For all altitudes the prevalence of I. ricinus was generally highest in the spring. Studies in Switzerland, Italy and the UK have shown I. ricinus larvae to have a bimodal activity pattern, peaking in the spring and autumn $[23,44,70]$ or 


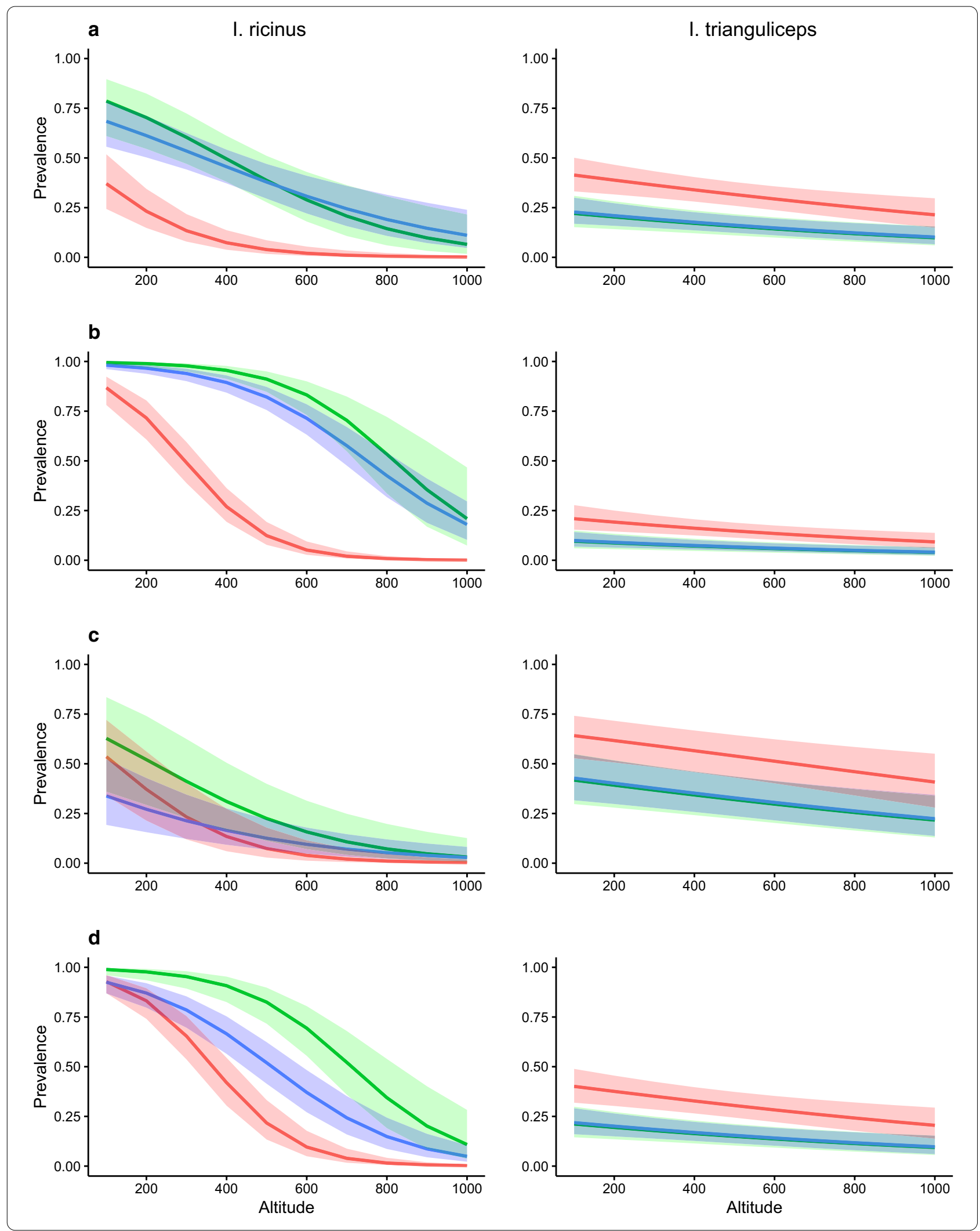


Table 1 Parameter estimates for the infestation prevalence on bank voles indicating the probability to be infested with at least one tick, using a binomial distribution model

\begin{tabular}{|c|c|c|c|c|}
\hline Parameters & Estimate & Standard error & $Z$ value & $P$ value \\
\hline \multicolumn{5}{|l|}{ Ixodes ricinus larvae } \\
\hline Intercept & 1.7429 & 0.5243 & 3.32 & 0.001 \\
\hline Study area Lærdal & 4.2441 & 0.5824 & 7.29 & $<0.001$ \\
\hline Altitude & -0.0044 & 0.0011 & -3.95 & $<0.001$ \\
\hline Sex female & -0.6724 & 0.1719 & -3.91 & $<0.001$ \\
\hline Year 2018 & -0.7789 & 0.3780 & -2.06 & 0.039 \\
\hline Season summer & -0.6515 & 0.5701 & -1.14 & 0.253 \\
\hline Season autumn & -1.6039 & 0.6048 & -2.65 & 0.008 \\
\hline Altitude: season summer & 0.0012 & 0.0012 & 1.03 & 0.305 \\
\hline Altitude: season autumn & -0.0023 & 0.0014 & -1.59 & 0.112 \\
\hline Study area Lærdal: altitude & -0.0029 & 0.0009 & -3.39 & 0.001 \\
\hline Study area Lærdal: season summer & -0.7681 & 0.4656 & -1.65 & 0.099 \\
\hline Study area Lærdal: season autumn & -1.5402 & 0.5646 & -2.73 & 0.006 \\
\hline Year 2018: season summer & -0.6665 & 0.4740 & -1.41 & 0.160 \\
\hline Year 2018: season autumn & 1.4512 & 0.4858 & 2.99 & 0.003 \\
\hline \multicolumn{5}{|l|}{ Ixodes trianguliceps larvae } \\
\hline Intercept & -1.1554 & 0.2461 & -4.70 & $<0.001$ \\
\hline Study area Lærdal & -0.9831 & 0.1690 & -5.82 & $<0.001$ \\
\hline Altitude & -0.0011 & 0.0003 & -3.37 & 0.001 \\
\hline Year 2018 & 0.9297 & 0.1785 & 5.21 & $<0.001$ \\
\hline Season summer & 0.0412 & 0.2257 & 0.18 & 0.855 \\
\hline Season autumn & 0.9133 & 0.2114 & 4.32 & $<0.001$ \\
\hline
\end{tabular}

Values in italics indicated significance for respective parameters

Baseline for study area is Lifjell 2017, spring season and male voles

only peaking in early summer [71]. In our study, almost equally high prevalences were found in the spring and summer of 2017, but prevalence dropped before the summer of 2018 when conditions were somewhat drier, and although humidity was not a reliable predictor of infestation for the two species, this could explain this drop in prevalence. Overall it would appear that I. ricinus larvae are not considerably inhibited by summer drought in this region and that the relatively cool and humid conditions of the two regions, compared to further south in Europe, enables it to continue questing as long as temperatures are high enough.

Larvae of I. trianguliceps were infesting voles during all active seasons of the year, but in contrast to I. ricinus, prevalence was highest in the autumn. Because I. trianguliceps is dependent on a very humid environment [72], it is possible that generally more rain and lower temperatures in the autumn lead to more favourable conditions for I. trianguliceps at this part of the year.

\section{The effect of host characteristics on prevalence}

Higher levels of parasitism of male hosts compared to female hosts is a common observation [73-75], and in this study vole sex was a determining factor in the prevalence of I. ricinus larvae, with males having higher infestations than females. As males roam around more than females [76, 77], the probability of males encountering ticks is higher, and this could explain the sex difference in the infestation rates of $I$. ricinus. However, no significant difference was found in infestation with $I$. trianguliceps larvae between male and female voles. As both male and female voles probably utilize burrows to a similar extent, both sexes should be equally exposed to infestations of $I$. trianguliceps larvae, which is in agreement with earlier findings $[44,46]$.

\section{Conclusions}

In this study we show that both I. ricinus and I. trianguliceps are present at much higher altitudes than what has previously been documented in Norway. With ticks 
expanding to higher altitudes there is an increasing risk of human and livestock infection with tick-borne diseases. The occurrence of tick-borne infections has both social and economical consequences, but to date these problems have been restricted to low-altitude areas in this region. Although human cases of tick-borne infections via I. trianguliceps are rare [15], this species helps maintain pathogens in enzootic cycles of small mammals $[50,68,78]$. Several recent studies have investigated the occurrence of tick-borne pathogens in I. ricinus ticks in Norway [79-81], but to date no investigation has yet focussed on disease dynamics in relation to altitude. In combination with the results of this study, an in-depth survey along altitudinal gradients investigating the prevalence of pathogens in ticks could provide valuable insights into the actual disease risk to humans and livestock in Norwegian mountains. As projections indicate a continuing trend in warming temperatures, particularly in the northern regions [82], the northward and upward progression of ticks under the influence of climate change is expected to continue in the future [83]. This will further expose humans and livestock to tick-borne infections in areas where no infection risk was present before.

\section{Appendices \\ Appendix 1}

See Fig. 4.

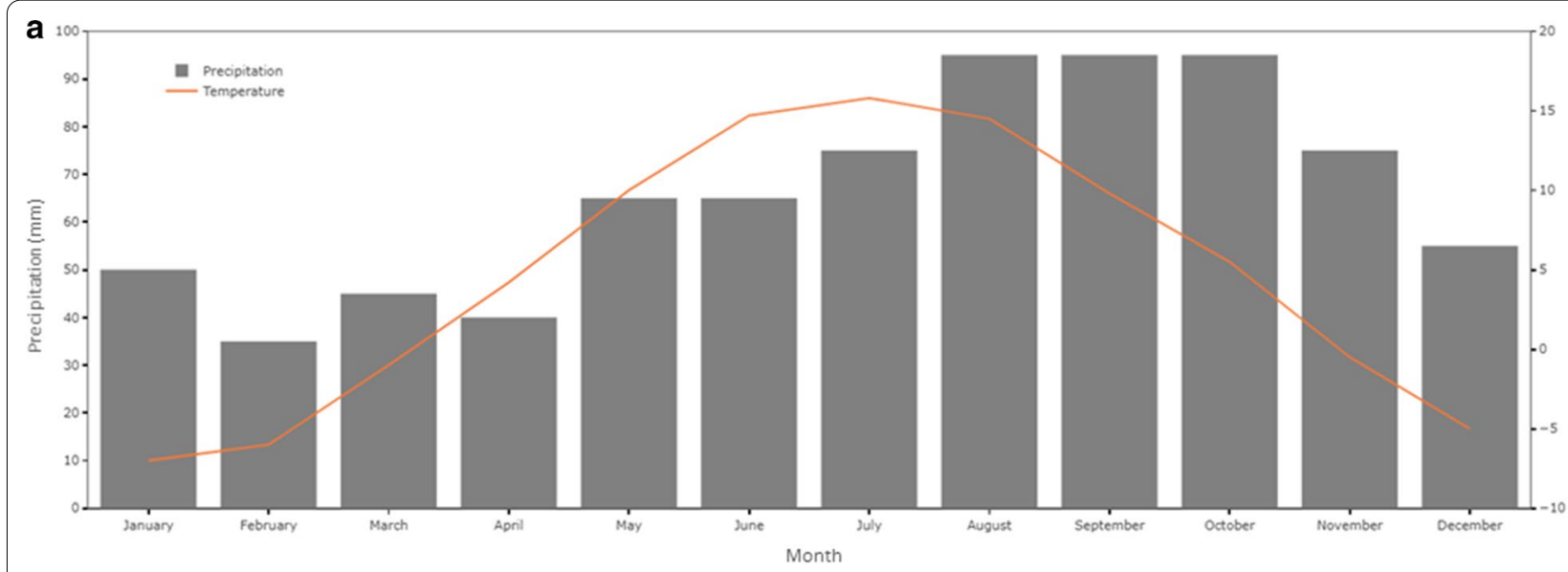

b

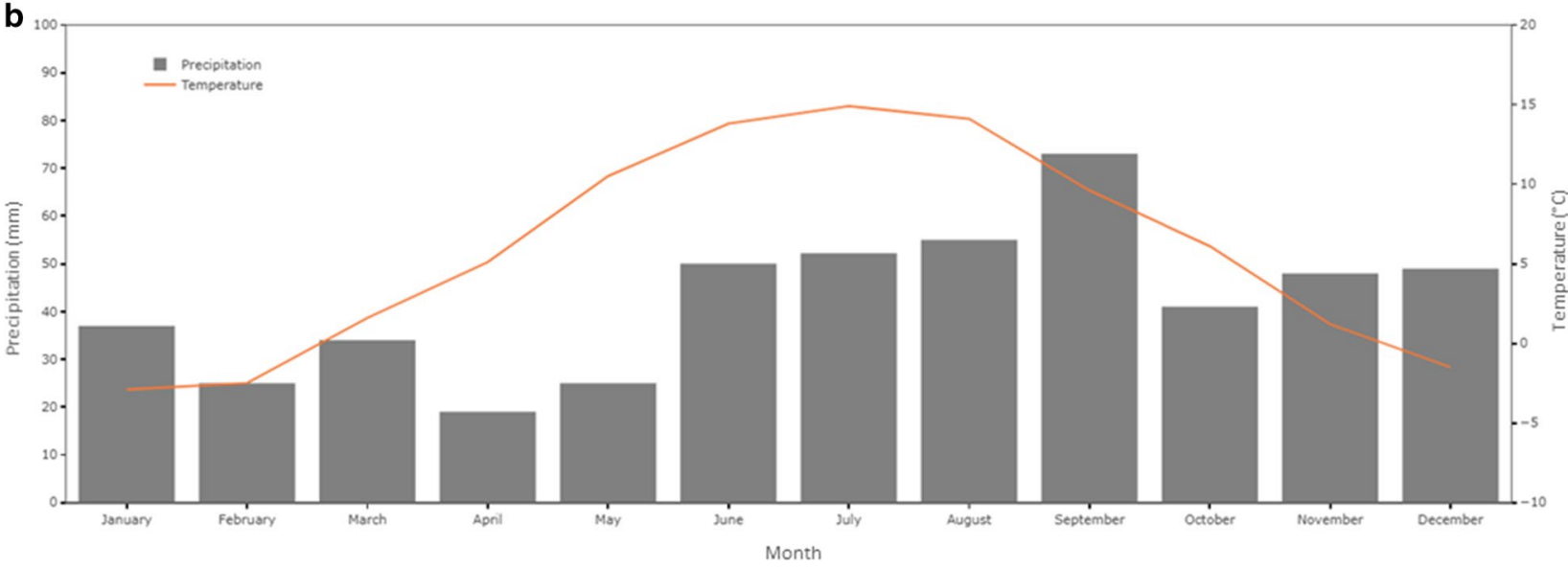

Fig. 4 Temperature and precipitation normals in Lifjell (a) and Lærdal (b). Data were obtained from the Norwegian Meteorological Institute 


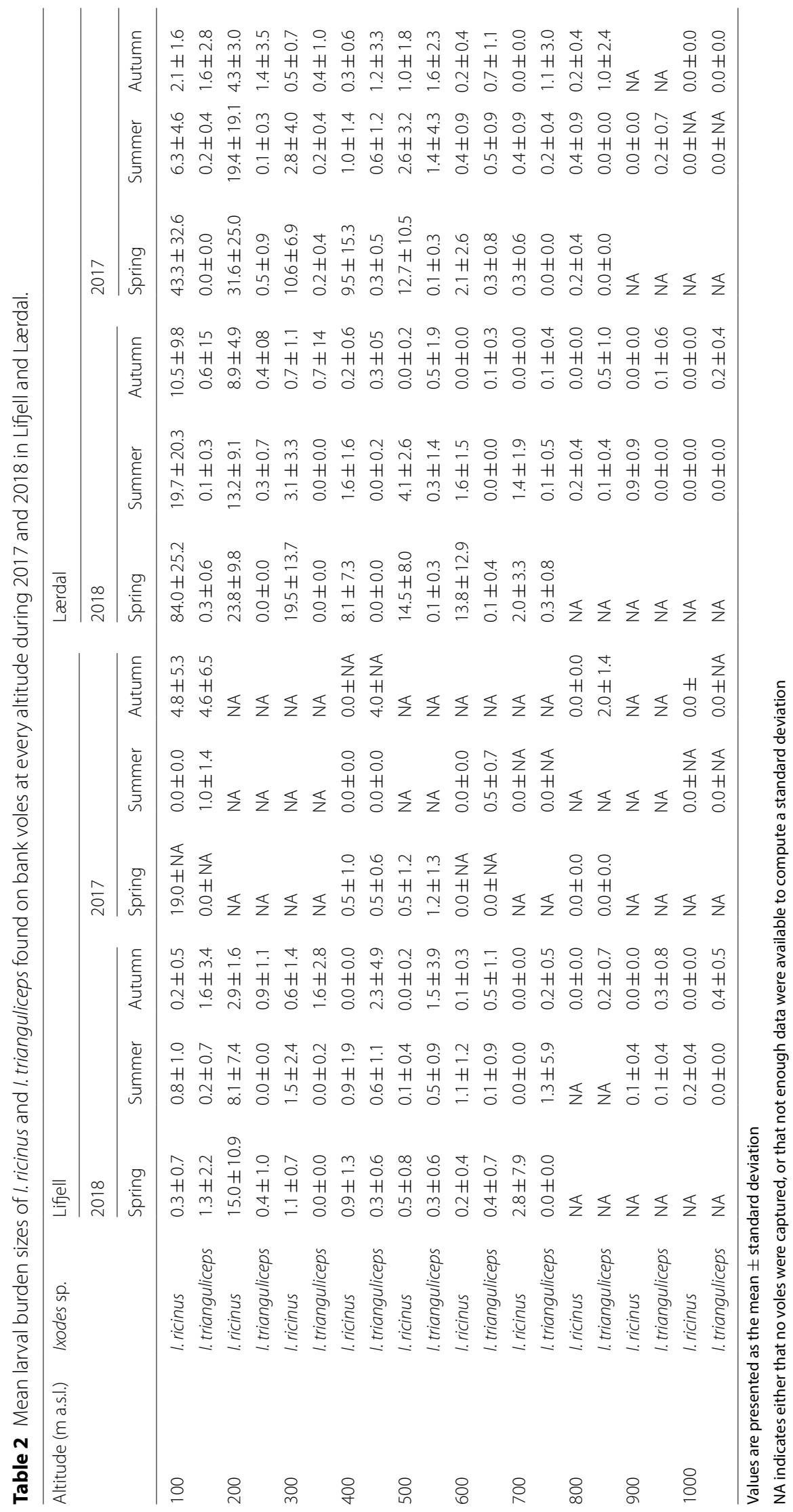




\section{Appendix 3}

See Table 3.

Table 3 Total number of hosts captured of each mammal species during 2017 and 2018, relative infestation rates and mean burden of I. ricinus and I. trianguliceps

\begin{tabular}{|c|c|c|c|c|c|}
\hline \multirow[t]{2}{*}{ Host species } & \multicolumn{3}{|l|}{ I. ricinus } & \multicolumn{2}{|c|}{ I. trianguliceps } \\
\hline & No. of captures & Prevalence $^{\mathrm{a}}$ & Mean burden ( \pm SD) & Prevalence $^{a}$ & Mean burden $( \pm S D)$ \\
\hline Apodemus flavicollis & 1 & 100.0 & $62.0 \pm N A$ & 100.0 & $1.0 \pm N A$ \\
\hline Apodemus sylvaticus & 23 & 56.5 & $6.4 \pm 13.5$ & 34.8 & $0.9 \pm 1.7$ \\
\hline Microtus agrestis & 130 & 18.5 & $1.7 \pm 7.9$ & 6.9 & $0.1 \pm 0.3$ \\
\hline Microtus oeconomus & 26 & 50.0 & $1.5 \pm 2.5$ & 23.1 & $0.3 \pm 0.7$ \\
\hline Mus musculus & 1 & 100.0 & $11.0 \pm N A$ & 0.0 & $0.0 \pm N A$ \\
\hline Myodes glareolus & 1325 & 46.8 & $3.6 \pm 9.0$ & 18.0 & $0.5 \pm 1.8$ \\
\hline Myodes rufocanus & 88 & 19.3 & $0.5 \pm 1.4$ & 19.3 & $0.6 \pm 2.0$ \\
\hline Neomys fodiens & 2 & 100.0 & $1.0 \pm 0.0$ & 50.0 & $7.5 \pm 10.6$ \\
\hline Sorex araneus & 1733 & 30.0 & $3.3 \pm 12.5$ & 20.8 & $0.8 \pm 3.4$ \\
\hline Sorex minutus & 16 & 31.3 & $0.4 \pm 0.7$ & 56.3 & $3.0 \pm 4.4$ \\
\hline
\end{tabular}

NA indicates that not enough captures were made to compute a standard deviation

a Prevalence is the relative infestation rate, given in percentage infestation

\section{Acknowledgements}

We would like to thank Britt Bjørkum, who kindly permitted us to perform part of the field work on her property, and who has greatly helped us with logistics and communication with other landowners. Our gratitude also goes out to all the assistants that participated in the field and laboratory work: D. Abiriga, I. Boine, K. Borlaug, I. Cacacho, M. Eldøy, P. Farsund, K. Floyd, E. Garvik, E. Haukø, T.-E. Holm, S. McElroy, M. Monalisa, A. Økelsrud, B. Pedersen, M. Rasmussen, J. Rietz, M. Ring, C. Robstad, L. Sortedal, M. Stensby, H. Strovassli, S. Sveinson and A.Vuontela.

\section{Author's contributions}

NP: data collection, formal analysis, manuscript writing; LK: formal analysis, manuscript writing, supervision; ØS: manuscript writing, supervision. All authors read and approved the final manuscript.

\section{Funding}

This study was funded by the University of South-Eastern Norway.

\section{Data availability}

The dataset is deposited at usn.figshare.com. https://doi.org/10.23642/usn. 12917960

\section{Ethics approval and consent to participate}

Permission for capturing small mammals was issued by the Norwegian Environment Agency (Miljødirektoratet, reference number: 2017/4651).

\section{Competing interests}

All contributing authors declare that there are no conflicts of interest involved in this study.

\section{Author details}

${ }^{1}$ Department of Nature, Health and the Environment, University of SouthEastern Norway, Bø, Norway. ${ }^{2}$ Department of Natural Sciences, University of Agder, Kristiansand, Norway.

Received: 10 September 2020 Accepted: 23 January 2021

Published online: 18 March 2021

\section{References}

1. Platts PJ, Mason SC, Palmer G, Hill JK, Oliver TH, Powney GD, et al. Habitat availability explains variation in climate-driven range shifts across multiple taxonomic groups. Sci Rep. 2019;9(1):1-10.

2. Garcia-Vozmediano A, Krawczyk Al, Sprong H, Rossi L, Ramassa E, Tomassone L. Ticks climb the mountains: ixodid tick infestation and infection by tick-borne pathogens in the Western Alps. Ticks Tick-borne Dis. 2020;1:101489.

3. Tombre IM, Oudman T, Shimmings P, Griffin L, Prop J. Northward range expansion in spring-staging barnacle geese is a response to climate change and population growth, mediated by individual experience. Glob Change Biol. 2019;25(11):3680-93.

4. Osland MJ, Feher LC. Winter climate change and the poleward range expansion of a tropical invasive tree (Brazilian pepper-Schinus terebinthifolius). Glob Change Biol. 2020;26(2):607-15.

5. Rubidge EM, Patton JL, Lim M, Burton AC, Brashares JS, Moritz C. Climateinduced range contraction drives genetic erosion in an alpine mammal. Nat Clim Change. 2012;2(4):285-8.

6. Smale DA, Wernberg T. Extreme climatic event drives range contraction of a habitat-forming species. Proc R Soc B. 2013;280(1754):20122829.

7. Berriozabal-Islas C, Rodrigues JFM, Ramírez-Bautista A, Becerra-López $J$, de Oca A. Effect of climate change in lizards of the genus Xenosaurus (Xenosauridae) based on projected changes in climatic suitability and climatic niche conservatism. Ecol Evol. 2018;8(14):6860-71.

8. Magalhaes I, Neves D, Santos F, Vidigal T, Brescovit AD, Santos A. Phylogeny of Neotropical Sicarius sand spiders suggests frequent transitions from deserts to dry forests despite antique, broad-scale niche conservatism. Mol Phyl Evol. 2019;140:106569.

9. Thompson CW, Finck EJ. A northward range extension of the hispid cotton rat (Sigmodon hispidus) in Missouri. The Prairie Naturalist. 2013;50:1.

10. Dawe KL, Boutin S. Climate change is the primary driver of white-tailed deer (Odocoileus virginianus) range expansion at the northern extent of its range; land use is secondary. Ecol Evol. 2016;6(18):6435-51.

11. Dobbertin $M$, Hilker N, Rebetez M, Zimmermann NE, Wohlgemuth $T$, Rigling A. The upward shift in altitude of pine mistletoe (Viscum album ssp austriacum) in Switzerland - the result of climate warming? Int J Biometeorol. 2005;50(1):40-7.

12. Lenoir J, Gégout J-C, Marquet P, De Ruffray P, Brisse H. A significant upward shift in plant species optimum elevation during the 20th century. Science. 2008:320(5884):1768-71. 
13. Rumpf SB, Hülber K, Klonner G, Moser D, Schütz M, Wessely J, et al. Range dynamics of mountain plants decrease with elevation. Proc Natl Acad Sci USA. 2018;115(8):1848-53.

14. Daniel M, Materna J, Hőnig V, Metelka L, Danielová V, Harčarik J, et al. Vertical distribution of the tick Ixodes ricinus and tick-borne pathogens in the northern Moravian mountains correlated with climate warming (Jeseníky Mts., Czech Republic). Cent Eur J Pub Health. 2009:17:3.

15. Jore $S$, Viljugrein $H$, Hofshagen $M$, Brun-Hansen $H$, Kristoffersen $A B$, Nygard K, et al. Multi-source analysis reveals latitudinal and altitudinal shifts in range of Ixodes ricinus at its northern distribution limit. Parasites Vectors. 2011:4:84

16. Martello E, Mannelli A, Ragagli C, Ambrogi C, Selmi M, Ceballos LA, et al. Range expansion of Ixodes ricinus to higher altitude, and co-infestation of small rodents with Dermacentor marginatus in the Northern Apennines Italy. Ticks Tick-borne Dis. 2014;5(6):970-4.

17. Daniel M. Influence of the microclimate on the vertical distribution of the tick Ixodes ricinus (L) in Central Europe. Acarology. 1993;34(2):105-13.

18. Estrada-Peña A, Mihalca AD, Petney TN. Ticks of Europe and North Africa: a guide to species identification. New York: Springer; 2018.

19. Sonenshine DE, Roe RM. Biology of ticks. Oxford: Oxford University Press; 2013.

20. Lindgren $\mathrm{E}$, Talleklint $\mathrm{L}$, Polfeldt T. Impact of climatic change on the northern latitude limit and population density of the disease-transmitting European tick Ixodes ricinus. Environ Health Perspect. 2000;108(2):119-23.

21. Leighton PA, Koffi JK, Pelcat Y, Lindsay LR, Ogden NH. Predicting the speed of tick invasion: an empirical model of range expansion for the Lyme disease vector Ixodes scapularis in Canada. J App Ecol. 2012;49(2):457-64.

22. Sormunen J, Kulha N, Klemola T (editors). Reducing tick bite risk in Finland-combining citizen science and GIS for predictive modelling of tick occurrence. EGU Gen Assembly Conf Abstr. 2017:7778.

23. Jouda F, Perret JL, Gern L. Ixodes ricinus density, and distribution and prevalence of Borrelia burgdorferi sensu lato infection along an altitudinal gradient. J Med Entomol. 2004;41(2):162-9.

24. Danielová V, Kliegrová S, Daniel M, Benes C. Influence of climate warming on tick-borne encephalitis expansion to higher altitudes over the last decade (1997-2006) in the Highland Region (Czech Republic). Cent Eur J Pub Health. 2008;16(1):4.

25. Cadenas FM, Rais O, Jouda F, Douet V, Humair P-F, Moret J, et al. Phenology of Ixodes ricinus and infection with Borrelia burgdorferi sensu lato along a north- and south-facing altitudinal gradient on Chaumont mountain Switzerland. J Med Entomol. 2007:44(4):683-93.

26. Gern L, Morán Cadenas F, Burri C. Influence of some climatic factors on Ixodes ricinus ticks studied along altitudinal gradients in two geographic regions in Switzerland. Int J Med Microbiol. 2008;298:55-9.

27. Daniel M, Danielova V, Kř́ž B, Jirsa A, Nožička J. Shift of the tick Ixodes ricinus and tick-borne encephalitis to higher altitudes in central Europe. Eur J Clin Microbiol Infect Dis. 2003;22(5):327-8.

28. Materna J, Daniel M, Metelka L, Harčarik J. The vertical distribution, density and the development of the tick Ixodes ricinus in mountain areas influenced by climate changes (The Krkonoše Mts., Czech Republic). Int J Med Microbiol. 2008;298:25-37.

29. Danielova V, Rudenko N, Daniel M, Holubova J, Materna J, Golovchenko $M$, et al. Extension of Ixodes ricinus ticks and agents of tick-borne diseases to mountain areas in the Czech Republic. Int J Med Microbiol. 2006;296(Suppl 40):48-53.

30. Aeschlimann A, Büttiker W, Diehl PA, Eichenberger G, Immler R, Weiss N. Présence d'Ixodes trianguliceps (Birula, 1895) et d'Ixodes apronophorus (Schultze, 1924) en Suisse (Ixodoidea; Ixodidae). Rev Suisse Zool. 1970;77:527-36.

31. Ogden NH, Maarouf A, Barker IK, Bigras-Poulin M, Lindsay LR, Morshed $M G$, et al. Climate change and the potential for range expansion of the Lyme disease vector Ixodes scapularis in Canada. Int J Parasitol. 2006;36(1):63-70.

32. Ogden NH, Bigras-Poulin M, Hanincova K, Maarouf A, O'Callaghan CJ, Kurtenbach K. Projected effects of climate change on tick phenology and fitness of pathogens transmitted by the North American tick Ixodes scapularis. J Theor Biol. 2008;254(3):621-32.

33. Suss J, Klaus C, Gerstengarbe FW, Werner PC. What makes ticks tick? Climate change, ticks, and tick-borne diseases. J Travel Med. 2008;15(1):39-45.
34. Perret $J$, Rais O, Gern L. Influence of climate on the proportion of /xodes ricinus nymphs and adults questing in a tick population. J Med Entomol. 2004:41(3):361-5.

35. Houghton E. Climate change 1995: The science of climate change: contribution of Working Group I to the second assessment report of the Intergovernmental Panel on Climate Change. Cambridge: Cambridge University Press; 1996

36. Talleklint $L$, Jaenson TG. Increasing geographical distribution and density of Ixodes ricinus (Acari: Ixodidae) in central and northern Sweden. J Med Entomol. 1998;35(4):521-6.

37. Jore S, Vanwambeke SO, Viljugrein H, Isaksen K, Kristoffersen AB, Woldehiwet Z, et al. Climate and environmental change drives /xodes ricinus geographical expansion at the northern range margin. Parasites Vectors. 2014;7:11.

38. Laaksonen M, Sajanti E, Sormunen JJ, Penttinen R, Hanninen J, Ruohomaki K, et al. Crowdsourcing-based nationwide tick collection reveals the distribution of Ixodes ricinus and I. persulcatus and associated pathogens in Finland. Emerg Microbes Infect. 2017;65:e31.

39. Hvidsten D, Frafjord K, Gray J, Henningsson A, Jenkins A, Kristiansen B, et al. The distribution limit of the common tick, Ixodes ricinus, and some associated pathogens in north-western Europe. Ticks Tick-borne Dis. 2020;2020:101388.

40. Randolph S, Green R, Hoodless A, Peacey M. An empirical quantitative framework for the seasonal population dynamics of the tick /xodes ricinus. Int J Parasitol. 2002:32(8):979-89.

41. Medlock JM, Hansford KM, Bormane A, Derdakova M, Estrada-Peña A, George J-C, et al. Driving forces for changes in geographical distribution of Ixodes ricinus ticks in Europe. Parasites Vectors. 2013;6(1):1.

42. Hillyard PD. Ticks of north-west Europe. Shrewsbury: Field Studies Council; 1996.

43. Bowman AS, Nuttall PA. Ticks: biology, disease and control. Cambridge: Cambridge University Press; 2008.

44. Cotton MJ, Watts $\mathrm{CH}$. The ecology of the tick /xodes trianguliceps Birula (Arachnida; Acarina; Ixodoidea). Parasitology. 1967;57(3):525-31.

45. Korenberg E, Lebedeva N. Distribution and some general features of the ecology of Ixodes trianguliceps Bir. in the Soviet Union. Folia Parasitol. 1969;162:143-52.

46. Mysterud A, Byrkjeland R, Qviller L, Viljugrein $\mathrm{H}$. The generalist tick Ixodes ricinus and the specialist tick /xodes trianguliceps on shrews and rodents in a northern forest ecosystem - a role of body size even among small hosts. Parasites Vectors. 2015;8:639.

47. Bown K, Begon M, Bennett M, Birtles R, Burthe S, Lambin X, et al. Sympatric Ixodes trianguliceps and Ixodes ricinus ticks feeding on field voles (Microtus agrestis): potential for increased risk of Anaplasma phagocytophilum in the United Kingdom? Vector-Borne Zoon Dis. 2006;6(4):404-10.

48. Piesman J, Gern L. Lyme borreliosis in Europe and North America. Parasitology. 2004;129(1):191-220.

49. Brown RN, Lane RS. Lyme disease in California: a novel enzootic transmission cycle of Borrelia burgdorferi. Science. 1992;256(5062):1439-42.

50. Turner AK, Beldomenico PM, Bown K, Burthe S, Jackson J, Lambin X, et al. Host-parasite biology in the real world: the field voles of Kielder. Parasitology. 2014;141(8):997-1017.

51. Stenseth NC. Geographic distribution of Clethrionomys species. Ann Zool Fen; 22(3):215-219.

52. Radzijevskaja J, Paulauskas A, Rosef O, Petkevicius S, Mazeika V, Rekasius T. The propensity of voles and mice to transmit Borrelia burgdorferi sensu lato infection to feeding ticks. Vet Parasitol. 2013;197(1-2):318-25.

53. Randolph S. Quantifying parameters in the transmission of Babesia microti by the tick Ixodes trianguliceps amongst voles (Clethrionomys glareolus). Parasitology. 1995;110(3):287-95.

54. Vayssier-Taussat M, Le Rhun D, Buffet JP, Maaoui N, Galan M, Guivier E, et al. Candidatus Neoehrlichia mikurensis in bank voles France. Emerg Infect Dis. 2012;18(12):2063-5.

55. Ogden NH, Bown K, Horrocks BK, Woldehiwet Z, Bennett M. Granulocytic Ehrlichia infection in ixodid ticks and mammals in woodlands and uplands of the U.K. Med Vet Entomol. 1998;12(4):423-9.

56. Hanincova K, Schafer SM, Etti S, Sewell HS, Taragelova V, Ziak D, et al. Association of Borrelia afzelii with rodents in Europe. Parasitology. 2003;126(1):11-20.

57. Sinski E, Pawelczyk A, Bajer A, Behnke JM. Abundance of wild rodents, ticks and environmental risk of Lyme borreliosis: a longitudinal study 
in an area of Mazury Lakes district of Poland. Ann Agric Environ Med. 2006;13(2):295

58. Lydecker HW, Banks PB, Hochuli DF. Counting ticks (Acari: Ixodida) on hosts is complex: a review and comparison of methods. J Med Entomol. 2019:56(6):1527-33.

59. Wilson DE, Lacher TE, Jr, Mittermeier RA (editors). Handbook of the mammals of the world, volume 7. Rodents II. Barcelona: Lynx Edicions; 2017.

60. De Pelsmaeker N, Korslund L, Steifetten O. Do bank voles (Myodes glareolus) trapped in live and lethal traps show differences in tick burden? PLoS One. 2020;15(9):e0239029.

61. Perret JL, Guigoz E, Rais O, Gern L. Influence of saturation deficit and temperature on Ixodes ricinus tick questing activity in a Lyme borreliosisendemic area (Switzerland). Parasitol Res. 2000;86(7):554-7.

62. Lindsjö J, Fahlman Å, Törnqvist E. Animal welfare from mouse to mooseimplementing the principles of the 3 Rs in wildlife research. JWildl Dis. 2016;52(2):65-77.

63. Mooring MS, MCKenzie AA. The efficiency of patch sampling for determination of relative tick burdens in comparison with total tick counts. Exp App Acarol. 1995;19(9):533-47.

64. Arthur DR. British ticks. London: Butterworths; 1963.

65. R Development Core Team. R: A language and environment for statistical conputing. Vienna: R Foundation for Statistical Computing; 2019.

66. Harrison A, Bennett NC. The importance of the aggregation of ticks on small mammal hosts for the establishment and persistence of tick-borne pathogens: an investigation using the R0 model. Parasitology. 2012;1:1-9.

67. Wickham H. ggplot2: elegant graphics for data analysis: Heidelberg: Springer; 2016

68. Bown K, Lambin X, Telford G, Ogden N, Telfer S, Woldehiwet Z, et al. Relative importance of Ixodes ricinus and /xodes trianguliceps as vectors for Anaplasma phagocytophilum and Babesia microti in field vole (Microtus agrestis) populations. App Environ Microbiol. 2008;74(23):7118-25.

69. Randolph SE. Seasonal dynamics of a host-parasite system: Ixodes trianguliceps (Acarina: Ixodidae) and its small mammal hosts. J Animal Ecol. 1975;44:2.

70. Dantas-Torres F, Otranto D. Seasonal dynamics of /xodes ricinus on ground level and higher vegetation in a preserved wooded area in southern Europe. Vet Parasitol. 2013;192(1-3):253-8.

71. Petney TN, Pfäffle MP, Skuballa JD. An annotated checklist of the ticks (Acari: Ixodida) of Germany. Sys App Acarol. 2012;17:2.
72. Estrada-Peña A Osacar J, Gortazar C Calvete C, Lucientes J. An account of the ticks of the northeastern of Spain (Acarina: Ixodidae). Ann Parasitol Hum Comp. 1992:67(2):42-9.

73. Schalk G, Forbes MR. Male biases in parasitism of mammals: effects of study type, host age, and parasite taxon. Oikos. 1997;1:67-74.

74. Zuk M, McKean KA. Sex differences in parasite infections: patterns and processes. Int J Parasitol. 1996;26(10):1009-24.

75. Cordoba-Aguilar A, Munguia-Steyer R. The sicker sex: understanding male biases in parasitic infection, resource allocation and fitness. PLoS One. 2013;8(10):e76246.

76. Haapakoski M, Ylönen H. Effects of fragmented breeding habitat and resource distribution on behavior and survival of the bank vole (Myodes glareolus). Popul Ecol. 2010;52(3):427-35.

77. Crawley M. Movements and home-ranges of Clethrionomys glareolus Schreber and Apodemus sylvaticus L. in north-east England. Oikos. 1969;1:310-9.

78. Jahfari S, Coipan EC, Fonville M, Van Leeuwen AD, Hengeveld P, Heylen D, et al. Circulation of four Anaplasma phagocytophilum ecotypes in Europe. Parasites Vectors. 2014;7(1):365.

79. Hvidsten D, Stuen S, Jenkins A, Dienus O, Olsen RS, Kristiansen BE, et al. Ixodes ricinus and Borrelia prevalence at the Arctic Circle in Norway. Ticks Tick-borne Dis. 2014;5(2):107-12.

80. Paulsen KM, Pedersen BN, Soleng A, Okbaldet YB, Pettersson JH, Dudman SG, et al. Prevalence of tick-borne encephalitis virus in Ixodes ricinus ticks from three islands in north-western Norway. APMIS. 2015;123(9):759-64.

81. Soleng A, Edgar KS, Paulsen KM, Pedersen BN, Okbaldet YB, Skjetne IEB, et al. Distribution of Ixodes ricinus ticks and prevalence of tick-borne encephalitis virus among questing ticks in the Arctic Circle region of northern Norway. Ticks Tick Borne Dis. 2018;9(1):97-103.

82. Smol JP. Climate Change: A planet in flux. Nature. 2012;483(7387):12-5.

83. Jaenson TG, Lindgren $E$. The range of Ixodes ricinus and the risk of contracting Lyme borreliosis will increase northwards when the vegetation period becomes longer. Ticks Tick-borne Dis. 2011;2(1):44-9.

\section{Publisher's Note}

Springer Nature remains neutral with regard to jurisdictional claims in published maps and institutional affiliations.
Ready to submit your research? Choose BMC and benefit from:

- fast, convenient online submission

- thorough peer review by experienced researchers in your field

- rapid publication on acceptance

- support for research data, including large and complex data types

- gold Open Access which fosters wider collaboration and increased citations

- maximum visibility for your research: over $100 \mathrm{M}$ website views per year

At BMC, research is always in progress.

Learn more biomedcentral.com/submissions 